тягнути гортань униз. Правильне їі відкриття досягається тільки відчуттям позіхання. Для того щоб ви ще легше змогли домогтися цього відчуття, уявіть собі, що у вас замерзли руки, і ви намагаєтеся зігріти їх своїм диханням. Видихаючи на складі «хо-о-о-о ...», у вас виходить тепле дихання. Тому можна сказати: щоб домогтися «теплого» звука на інструменті, потрібно дихати теплим повітрям.

Слід зазначити, що заняття спортом, особливо плаванням, бігом, катанням на лижах позитивно впливає на розвиток дихальної мускулатури. Під час плавання, як відомо, виробляється швидкий і глибокий вдих і відносно тривалий видих у воду, що багато в чому схоже на здійснення вдиху і видиху під час гри на духових інструментах. Найприродніше наше дихання функціонує під час сміху. Тому більше смійтеся, але і про роботу м'язів не забувайте.

Отже, ми навели основні педагогічні рекомендації щодо пристосування дихальної системи до умов гри на духових інструментах, а також найважливіші вправи для розвитку дихання музиканта-духовика.

\title{
Література
}

1. Апатский В. Н. Основы теории и методики духового музыкальноисполнительскогоискусства: [учеб. пособие] / В. Н. Апатский. - К. : НМАУ им. П. И. Чайковского, 2006. - 432 с.

2. Вовк Р. А. Історія, акустична природа і виразні можливості аплікатури кларнета: дис.... канд. мистецтвознавства: 17.00.03 / Р. А. Вовк. - К., 2004. - 204 с.

3. Діков Б. Методика навчання гри на духових інструментах / Б. Діков. - М., 1962. - 116 с.

4. Орвид Г. Некоторые объективные закономерности звукообразования и искусства игры на трубе / Г.Орвид. - М. : МГК. - 30 с.

5. Рудницька О. П. Педагогіка: загальна та мистецька / О. П. Рудницька. - К., 2002. - 270 с.

6. Федоров А. Методика навчання гри на духових інструментах / А. Федоров. - М., 1975. $-158 \mathrm{c}$.

Стаття надійшла до редакції 12.04.2012 р.

\section{СТРУКТУРА ТА ЗМІСТ ІНТЕЛЕКТУАЛЬНО-ТВОРЧОГО ПОТЕНЦАЛУ ВЧИТЕЛЯ ТЕХНОЛОГІЙ}

Єфіменко С. М. Структура та зміст інтелектуально-творчого потенціалу вчителя технологій.

У статті запропоновано узагальнену структуру інтелектуально-творчого потенціалу вчителя технологій. Розкрито структурні складники изього особистісного утворення.

Ключові слова: інтелектуальний потенціал, творчий потенціал, інтелектуально-творчий потенціал вчителя технологій.

Ефименко С. Н. Структура и содержание интеллектуально-творческого потенциала учителя технологий.

В статье предложена обобщенная структура интеллектуально-творческого потенциала учителя технологий. Раскрыты структурные составляющие данного личностного образования.

Ключевые слова: интеллектуальный потенцичал, творческий потенциал, интеллектуально-творческий потенцииал учителя технологий.

Efimenko S. The structure and content, creativity intelektualno teacher technology.

The article offers the generalized structure of intellectually-creative potential of teacher of technologies. An author characterizes the structural components of this personality formation.

Key words: intellectual potential, creative potential, intellectually-creative potential of teacher of technologies. 
Постановка проблеми. Людський розум має особливу властивість: на основі пізнавальної мотивації та потенційної можливості мислення продукувати нові ідеї. Продукування нових ідей детермінує появу нової потенції й мотивації, що зумовлює розвиток особистості. Отже, інтелектуально-творча діяльність людини залежить від внутрішнього потенціалу, поштовху, а також від участі в цій діяльності творчої та інтелектуальної сфер суб'єктів діяльності.

В умовах реформування вищої педагогічної школи особливої актуальності набуває проблема оновлення змісту професійної підготовки майбутніх учителів, зокрема вчителів технологічної освіти до творчої педагогічної діяльності. Постає необхідність у професійній підготовці вчителів, здатних до інтелектуально-творчої праці, компетентного розв'язання педагогічних завдань, професійного саморозвитку та актуалізації власного потенціалу. Саме тому проблема дослідження інтелектуально-творчого потенціалу (ITП) вчителя технологій та шляхів його діагностики є актуальною і відіграє важливу роль у теорії та практиці професійної підготовки майбутнього вчителя технологічної освіти.

Аналіз останніх досліджень та публікацій. Проблема вивчення інтелекту, інтелектуальних здібностей, інтелектуального (розумового) розвитку $\epsilon$ однією 3 найбільш досліджуваних та водночас найактуальніших проблем психолого-педагогічних досліджень (Г. Айзенк, Б. Ананьєв, Д. Богоявленська, А. Брушлінський, Дж. Гілфорд, В. Дружинін, Ж. Піаже, В. Крамаренко, О. Леонтьєв, С. Рубінштейн, М. Смульсон, Р. Стернберг, Н. Тализіна, О. Тихомиров, М. Холодна та інші). Інтелектуальний потенціал $є$ предметом досліджень В. Арістова, Г. Кургунцевої, Л. Мішіної, М. Якунькіної та інших науковців.

У кінці XIX - початку XX століття над різними аспектами загальної теорії творчості працювали зарубіжні (Е. де Боно, П. Вайцвайг, Т. Любарт, Г. Нойнер, Р. Стернберг та інші) та вітчизняні (Є. Ільїн, О. Лук, В. Моляко, Я. Пономарьов, В. Роменець, Л. Смольська, О. Тихомиров, К. Торшина, Р. Швай та інші) науковці. Зміст та структурні складники творчого потенціалу особистості досліджують Д. Барабоха, Є. Ільїн, Н. Медведєва, школа В. Моляко, О. Приходько та інші.

Проблему формування творчої особистості вчителя в процесі професійної підготовки досліджують В. Кан-Калик, М. Нікандров, Н. Кічук, П. Кравчук, О. Кривильова, Ю. Кулюткін, О. Морозов, Н. Побірченко, Н. Посталюк, М. Поташник, С. Сисоєва, Д.Чернилевський та інші науковці. Система професійної підготовки, розвитку особистості студента як суб'єкта інноваційних освітніх процесів, його наукового та творчого стилю мислення проаналізована в роботах О. Андреєва, І. Багаєвої, Н. Гузій, А. Деркач, В. Радула, М. Резниченко, В. Сластьоніна, С. Смірнова, Ю. Фокіна та інших дослідників. Професійна підготовка вчителя технологій $є$ об'єктом наукових розвідок С. Батишева, О. Коберника, В. Сидоренка, Г. Терещука, Д. Тхоржевського та інших науковців.

Під час аналізу цих досліджень ми виявили: суперечність між існуючим недостатньо високим рівнем ІТП молоді та замовленням на його 
високий рівень; недостатність вияву психологічної природи ІТП людини; відсутність єдиного підходу до чіткого розуміння змісту поняття «інтелектуально-творчий потенціал Учителя», окреслення його структурних складових, рівнів сформованості, чинників його формування і розвитку, стимулів та механізмів його виявлення. Ми з'ясували, що ПИТАННЯ розвитку ІТП майбутнього вчителя технологій залишаються недостатньо розроленими в загальному потоці педагогічних досліджень, що зумовлює актуальність виокремлення цієї проблематики дослідження в самостійний напрям.

Метою статті є розкриття структурних складників інтелектуальнотворчого потенціалу вчителя технологій.

Виклад основного матеріалу дослідження. На основі аналізу зазначених наукових джерел ми з'ясували змістовну єдність потенціалу 3 інтелектом i творчістю особистості, що надає підстави інтегрувати їх у спільне бінарне поняття - інтелектуально-творчий потенціал. На нашу думку, інтелектуально-творчій потенціал $є$ не окремою рисою особистості, а iii інтегративною якістю, до комплексу якої входять когнітивні, мотиваційні, інтелектуальні і творчі особистісні якості та властивості людини.

Поняття «інтелектуально-творчий потенціал вчителя технологій» ми розглядаємо як сукупність властивостей і якостей особистості вчителя, як потенційну здатність до інтелектуально-творчого саморозвитку особистості, що відображає міру можливостей актуалізації внутрішніх ресурсів особистості в продуктивній творчій педагогічній діяльності на основі єдності творчого й інтелектуального потенціалу. Це поняття характеризується здатністю вчителя продукувати нові ідеї, орієнтуватися у швидкоплинному інформаційному полі, здатності до самостійного, творчого розв'язання проблем, швидкого виходу 3 нестандартних ситуацій, активної участі в перетворенні навколишнього світу.

Складники інтелектуально-творчого потенціалу вчителя технологій (пізнавальна мотивація до інтелектуально-творчої діяльності, інтелектуальний потенціал, творчий потенціал) та їх показники у поєднані з принципами і методами їх діагностування складають узагальнену структуру ITП учителя технологій (рис. 1).

Розкриємо зміст основних структурних складників інтелектуальнотворчого потенціалу вчителя технологій.

Пізнавальну мотивацію до інтелектуально-творчої діяльності ми розглядаємо як один 3 головних компонентів інтелектуально-творчого потенціалу вчителя технологій. Адже навчально-пізнавальна, трудова діяльність людини, а також ефективність розв'язання проблемних ситуацій, творчих завдань значною мірою залежать від мотиваційної сфери особистості. Мотивація є чинником подальшого розвитку. Вона стимулює протікання розумових процесів, мобілізує творчі сили на пошук і розв'язання пізнавальних задач, здобуття знань і умінь, є джерелом інтелектуальної, творчої активності, сприяє здійсненню самоосвіти.

До мотиваційного компоненту ІТП учителя технологій ми відносимо складники, які зумовлюють розумову і творчу спрямованість особистості вчителя: 


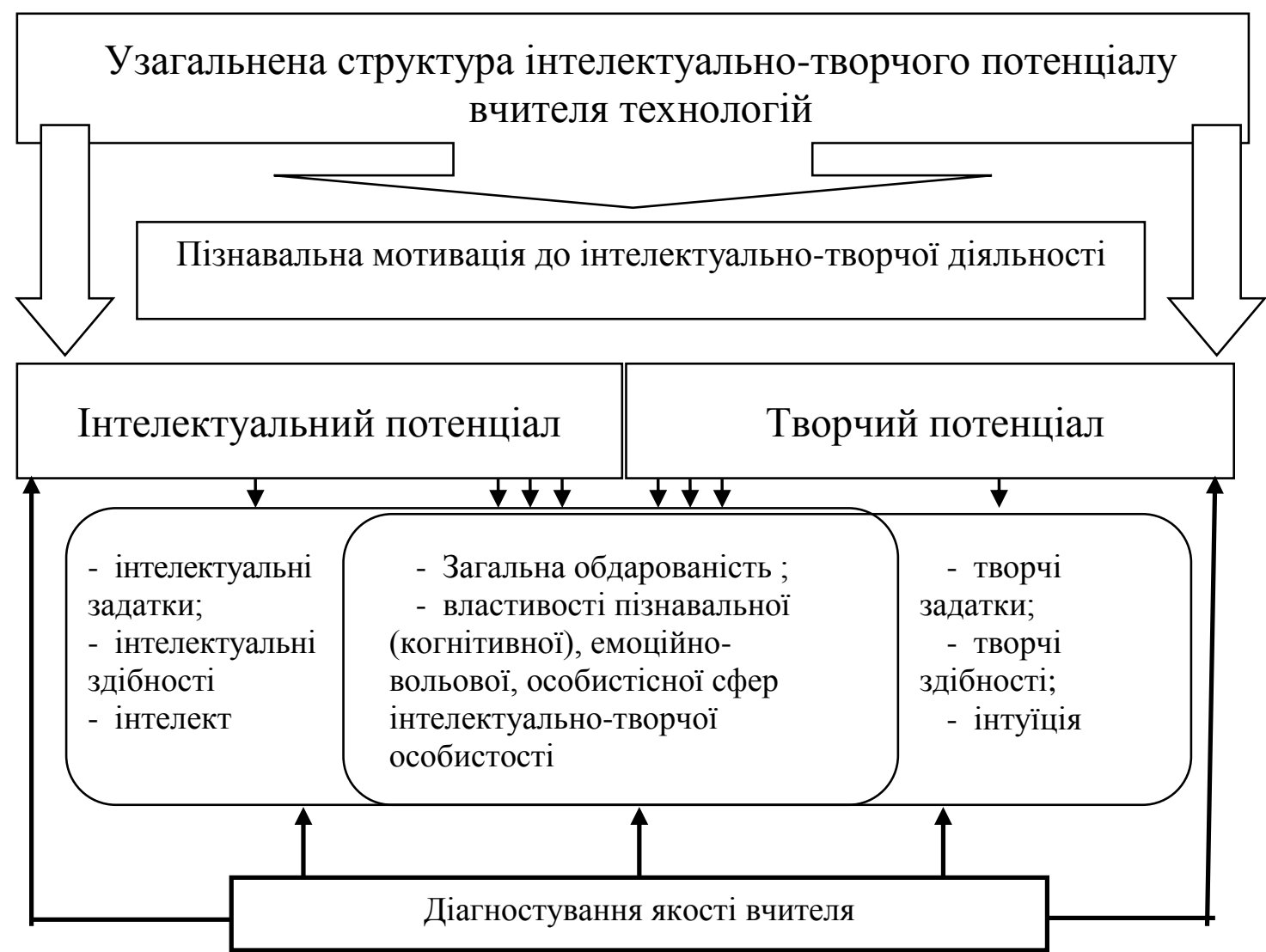

Рис.1. Схематичне зображення інтелектуально-творчого потенціалу вчителя технологій

- сукупність внутрішніх пізнавальних мотивів;

- потреба в реалізації індивідуального стилю діяльності;

- потреба у творчому виконанні діяльності;

- потреба в розумовому навантаженні;

- прагнення до розширення кругозору, поглиблення і систематизації знань, вдосконалення навичок, котрі знадобляться в майбутньому професійному житті;

- прагнення до краси і гармонії;

- прагнення до пошуку оптимальних психолого-педагогічних рішень;

- прагнення досягти ефективних результатів у професійній діяльності;

- прагнення до самореалізації у педагогічній діяльності;

- спрямованість інтересів;

- широке коло інтересів;

- високий пізнавальний інтерес;

- інтерес до процесу і результатів інтелектуально-творчої діяльності;

- інтерес до пошуково-дослідницької діяльності;

- інтерес до всього нового;

- інтерес до пошуку нової інформації;

- інтерес до пошуку і розв'язання проблем;

- інтерес до недоліків і парадоксів, незвичних властивостей об'єктів;

- бажання розвивати свої інтелектуальні і творчі здібності. 
Важливим компонентом структури інтелектуально-творчого потенціалу вчителя технологій є творчий потенціал. Ми розуміємо поняття «творчий потенціал» як інтегрований внутрішній резерв людини, що становить сукупність творчих можливостей, які за відповідних умов активізуються в стані креативності.

На основі вивчення наукової літератури ми розглянули поняття «творчий потенціал учителя». Узагальнено це поняття характеризується як інтегрована здібність учителя відмовитися від стереотипних способів мислення, потенційна можливість до творчої діяльності, сприйняття недоліків та прогалин в знаннях і намагання заповнити їх творчими ідеями, здатність швидко реагувати на нестандартні проблемні ситуації (життєві і професійні).

До складників творчого потенціалу вчителя технологій ми відносимо такі структурні компоненти:

- творчі задатки (чуткість зору, розвиток моторики рук тощо);

- творчі здібності (дивергентні здібності, здібності до педагогічної, наукової, художньої (дизайнерської), технічної (конструкторської i технологічної) творчості, здібність бачити шлях розв'язання проблеми в інформації з різних галузей знань, здібності до переносу знань і вмінь у нові ситуації, здібності до вдосконалення об'єкта праці, комбінаторні здібності, здібності до прогнозування тощо);

- розвинена інтуїція.

Творчий потенціал характеризує творчий складник досліджуваного нами інтелектуально-творчого потенціалу вчителя технологій. Інтелектуальний складник ITП характеризує інтелектуальний потенціал. На нашу думку, інтелектуальний потенціал - це величина, яка, завдяки розвитку своїх структурних компонентів, з часом змінюється, збільшуючи показники інтелекту.

Ми розглядаємо поняття «інтелектуальний потенціал вчителя технологій» як внутрішню спонукальну силу, що стимулює до пізнавальної діяльності, як абстрактну можливість мисленнєвої діяльності. Цей потенціал є багатогранним i, відповідно до запропонованої нами схеми, включає такі структурні компоненти:

- інтелектуальні задатки;

- інтелектуальні здібності (конвергентні здібності, здібності до навчання, здібності до аналізу, здібності до синтезу, здібності до узагальнення, здібності до класифікації, здібності до систематизації, здібності до порівняння, здібності до виокремлення головного, здібності до опису процесів і явищ, здібності до пояснення, здібності до обгрунтування, здібності до доведення, здібності вчасно відмовитися від хибної гіпотези, здібності до логічного, абстрактного, раціонального мислення тощо);

- інтелект (біологічний, психометричний $(100<\mathrm{IQ}<116)$, емоційний, соціальний, практичний, академічний).

Виходячи з запропонованої нами узагальненої структури інтелектуальнотворчого потенціалу вчителя технологій, можна визначити зв'язок між інтелектуальним та творчим потенціалом. Цей взаємозв'язок характеризується 
сукупністю властивостей i якостей, притаманних інтелектуально-творчій особистості. На наш погляд, ця сукупність властивостей і якостей інтелектуальнотворчої особистості є необхідним складником ITП, адже творчий процес 3 інтелектуальним наповненням ггрунтується на системі індивідуальнопсихологічних особливостей людини, які забезпечують його перебіг i $\epsilon$ умовою його успішного виконання. На основі аналізу зарубіжних та вітчизняних наукових підходів до проблеми дослідження якостей i ознак творчої й інтелектуально розвиненої особистості, можемо зробити висновок про те, що розумним, творчим людям притаманна сукупність характерних для них рис. Ми об'єднали ці риси у 3 групи.

Першу групу складають властивості пізнавальної (когнітивної) сфери:

- особливості відчуттів та сприймання: висока сенсорна чутливість, відчуття форми, пропорцій, композиційної завершеності, кольорових співвідношень, самостійність, осмисленість, синтетичність (цілісність) сприймання, здатність до звільнення від фіксованої спрямованості сприймання, підвищена реакція на деталі, уміння бачити неточність, дефекти, незвичність й унікальність об'єктів, проблемність сприймання, творчість сприймання (уміння дивуватися очевидному, уміння знаходити цікаве в нецікавому, уміння знаходити нове в забутому старому, уміння у звичайному побачити нове, оглянути його в новому ракурсі, побачити незвичайний взаємозв'язок між предметами) тощо;

- особливості мислення: пошуково-перетворювальний, творчий, законодавчий, синтетичний стиль мислення, альтернативність, самостійність, швидкість, гнучкість, оригінальність, унікальність, нестандартність, конструктивність, нешаблонність, стратегічність, системність, кмітливість, ерудованість, винахідливість мислення, глибина і широта мислення, переважання інтуїтивного, наочнообразного, дивергентного, продуктивного (творчого), професійного мислення, вміння зводити воєдино різноманітні ідеї, здатність до швидкого і міцного набуття знань і вмінь, здатність мислити на кілька ходів уперед тощо;

- особливості пам'яті: швидкість, легкість і міцність запам'ятовування, готовність (оперативність) пам'яті надавати необхідну інформацію в потрібну хвилину, переважання емоційно-образної та словесно-логічної пам'яті, асоціативність пам'яті тощо;

- особливості уваги: розвинена опосередкована та безпосередня увага, здатність до успішного та швидкого іiі переключення, зосередженість уваги, стійкість та об'єм уваги, тонка спостережливість тощо;

- особливості уяви: багатство уяви (уявлення потенційного, абстрактного, фантастичного), схильність до доповнення, розширення та збагачення досвіду за рахунок уяви, легкість у створенні образів тощо;

- особливості мови: достатній словниковий запас для висловлення думок, швидкість мовлення (легкість формулювання слів) тощо.

Другу групу якостей i ознак інтелектуально-творчої особистості вчителя технологій складають властивості емоційно-вольової сфери:

- особливості волі: здатність концентрувати інтелектуальні і творчі зусилля, здатність відкладати проблему в бік, старанність, наполегливість, 
відповідальність, рішучість, цілеспрямованість, енергійність, вимогливість до себе, необмежене терпіння в тривалому обмірковуванні проблеми, уміння доводити почату справу до кінця тощо;

- особливості емоцій та почуттів: емоційна активність, висока емоційна чутливість, емоційне забарвлення інтелектуально-творчої діяльності (емоції здивування, здогаду, сумніву, успіху-неуспіху, впевненості у своїх силах та здібностях у проблемних ситуаціях, задоволення від процесу творчості), позитивність у сприйманні, оптимізм і почуття гумору, почуття прекрасного, естетичні почуття тощо.

Третю групу якостей і ознак інтелектуально-творчої особистості вчителя технологій складають властивості особистісної сфери:

- високий рівень моральної свідомості;

- високий рівень загальної культури;

- високий рівень самооцінки;

- сформованість педагогічного «Я»;

- домінування в міжособистісних стосунках;

- здатність до рефлексії;

- нонконформізм;

- здатність до проблемного бачення, виявлення суперечностей;

- здатність до подолання інерції, критичності, ригідності мислення;

- готовність приймати рішення;

- незалежність і самостійність у прийнятті рішень;

- ініціативність;

- невтомність у пошуках;

- відкритість новому досвіду;

- відданість своїй справі;

- здатність легко пристосовуватися до нових фактів і обставин;

- вміння відмовитися від застарілих поглядів, стереотипів;

- оригінальний підхід до стандартних завдань;

- здатність до творчої інтерпретації пізнавального досвіду;

- намагання щось змінити в об'єктах, удосконалити їх;

- здатність до знаходження привабливості в труднощах;

- різнобічність і гармонійність особистісного розвитку;

- психологічна готовність до пошуку шляхів розв'язання творчих задач з урахуванням системи вимог, зумовлених професією та моральними принципами тощо.

Ми вважаємо, що розумна, творча особистість формується в єдності, взаємозв'язку і позитивній спрямованості всіх цих якостей. Така єдність високого рівня когнітивних, емоційно-вольових, особистісних якостей разом із загальною обдарованістю (інтелектуальною і творчою) забезпечує успіх реалізації потенціалу в інтелектуально-творчій, навчальній, професійній діяльності майбутнього спеціаліста. Зазначені властивості i якості інтелектуально-творчої особистості взагалі і творчого педагога зокрема, мають вагоме значення для розкриття можливостей їх формування i розвитку в процесі професійної підготовки студентів. 
Висновки. Запропонована структура інтелектуально-творчого потенціалу вчителя технологій розкриває складність цього особистісного утворення i наявність великої кількості інтегрованих компонентів (спадкових і набутих), за допомогою яких досягаються творчі результати.

Психолого-педагогічний аспект проблеми ІТП пов'язаний з виявленням, діагностуванням та розвитком його компонентів. Перспективи подальших розвідок у даному напрямку передбачають розроблення й застосування психологопедагогічних умов організації інтелектуально-творчої діяльності задля формування названого особистісного утворення в майбутніх учителів технологій.

Завдання викладачів - сформувати інтелектуально-творчий потенціал у майбутніх учителів технологій, завдання майбутнього фахівця - ефективно його використати і реалізувати в майбутній професійній діяльності.

\section{Література}

1. Айзенк Г. Ю. Интеллект: новый взгляд / Г. Ю. Айзенк ; [пер. с англ. А. В. Александровой] // Вопросы психологии. - 1995. - № 1. - С. 111-131.

2. Ильин Е. П. Психология творчества, креативности, одаренности / Евгений Павлович Ильин. - СПб. : Питер, 2009. - 434c. - (Серия «Мастера психологии»)

3. Лук А. Н. Мышление и творчество / Александр Наумович Лук. - М. : Политиздат, 1970. - 144 с. - (Философ. б-чка для юношества).

4. Мішіна Л. М. Інтелектуальний потенціал творчої особистості / Л. М. Мішіна // Рідна школа. - 2009. - № 10. - С. 15-18.

5. Панкратова А. А. Практический, социальный и эмоциональный виды интеллекта: сравнительный анализ / А. А. Панкратова // Вопросы психологии. - 2010. № 2. - С. 111-119.

6. Психологічне дослідження творчого потенціалу особистості : [монографія] / авт. кол., наук. керівник В. О. Моляко. - К. : Педагогічна думка, 2008. - 208 с.

7. Холодная М. А. Психология интеллекта: парадоксы исследования : [моногафия] / Марина Александровна Холодная. - [2-е изд., перераб. и доп.]. - СПб. : Питер, 2002. - 272 с.

Стаття надійшла до редакції 16.05.2012 p.

УДК 371.15

Н. Кипиченко, викладач, Київський університет імені Бориса Грінченка

\section{КОМУНІКАТИВНА КОМПЕТЕНТНІСТЬ МАЙБУТНЬОГО ВЧИТЕЛЯ ПОЧАТКОВОЇ ШКОЛИ ЯК ПСИХОЛОГО-ПЕДАГОГІЧНА ПРОБЛЕМА}

Кипиченко Н. Комунікативна компетентність майбутнього вчителя початкової школи як психолого-педагогічна проблема.

У статті розглянуто основні підходи вітчизняних $і$ зарубіжних науковиів до визначення сутності та структури комунікативної компетентності; уточнено сутність та зміст поняття «комунікативна компетентність учителя початкової школи», визначено структурні компоненти комунікативної компетентності майбутнього вчителя початкової школи.

Ключові слова: компетентність, компетенція, комунікативна компетентність майбутнього вчителя початкової школи, мовна компетенція, мовленнєва компетенція, сочіолінгвістична компетенція. 